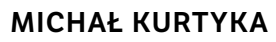

\title{
Polityka klimatyczna Polski na tle międzynarodowym
}

Z Michałem Kurtyką, ministrem klimatu i środowiska, rozmawia Wojciech Jakóbik

\section{Poland's climate policy against an international background:}

Wojciech Jakóbik's interview with Michał Kurtyka,

Minister of Climate and Environment 

Czy debata o polityce klimatycznej posiada już jeden ustalony dogmat świadczący o tym, że taka polityka jest konieczna ze względu na antropogeniczne zmiany klimatu? ${ }^{1}$

Chyba nikt nie ma już wątpliwości co do konieczności przeciwdziałania zmianom klimatycznym i idącym za tym zagrożeniom dla życia. Wszyscy jesteśmy odpowiedzialni za to, w jakim stanie przekażemy naszą planetę kolejnym pokoleniom. Dążenie do zmniejszenia udziału $\mathrm{CO}_{2} \mathrm{w}$ atmosferze jest naturalnym krokiem ku lepszemu życiu, np. bez smogu i innych zagrożeń dla naszego zdrowia.

Polityka klimatyczna, aby zadziałać - co z punktu widzenia stosunków międzynarodowych jest nie lada wyzwaniem - musi mieć charakter globalny. Jak ocenia Pan stan gry największych potęg międzynarodowych $\mathrm{w}$ tej sprawie?

To prawda, zmiany klimatu to problem globalny i żadne państwo nie jest w stanie rozwiązać go samodzielnie. Świat doskonale to rozumie, czego dowodem są takie gesty jak uzgodnienie i rekordowo szybkie wejście w życie Porozumienia paryskiego, które zobowiązuje wszystkie państwa do ochrony klimatu. Oczywiście poza gestami liczą się też konkretne działania podejmowane na szczeblu krajowym. I pod tym względem jest coraz lepiej, mimo - a może właśnie dzięki - wyzwaniu odbudowy gospodarki po pandemii covid-19. Do Unii Europejskiej, która jeszcze w grudniu zeszłego roku ogłosiła cel neutralności klimatycznej do 2050 r., dołączyły niedawno Japonia i Korea - z celem neutralności „węglowej” do 2050 r., oraz Chiny z takim celem wytyczonym na 2060 r. Już teraz można powiedzieć, że wielkie mocarstwa wkroczyły na ścieżkę wiodącą do zeroemisyjnej gospodarki i to jest bardzo dobra wiadomość dla całego świata. Produkty i usługi, które powstaną na potrzeby tych rynków, będą dostępne dla wszystkich, obniżając koszty transformacji gdzie indziej. Co ważne, dzięki temu również mocarstwa nie będą obawiały się o konkurencję w handlu między sobą poprzez obniżanie standardów środowiskowych, a zaczną bardziej myśleć o wyścigu na polu innowacji w technologiach zeroemisyjnych.

1 Rozmowa została przeprowadzona 30 października $2020 \mathrm{r}$. 
Jakie jest miejsce Polski w tej międzynarodowej dyskusji? Z jednej strony bronimy wsparcia transformacji energetycznej, tłumacząc się biedą, a z drugiej jesteśmy w gronie krajów najbardziej rozwiniętych na świecie.

Niemniej - mimo zmian transformacyjnych, jakie nastąpiły w ostatnich latach - polski sektor elektroenergetyczny opiera się w znacznym stopniu na wyeksploatowanych elektrowniach węglowych, ponieważ ok. 70 proc. mocy ma ponad 30 lat. To powoduje, że stanęliśmy przed wyzwaniem zrealizowania ogromnych inwestycji w celu zbudowania nowego systemu energetycznego w najbliższych dziesięcioleciach.

Polska polityka energetyczna, zwłaszcza po 1989 r., w znaczącym stopniu skupiała się na procesie modernizacji sektora elektroenergetycznego. W kraju sukcesywnie udaje się ograniczać emisję gazów cieplarnianych. Cały czas podejmujemy liczne działania umożliwiające osiągnięcie zakładanych celów. Inwestujemy w badania i rozwój nakierowany na nowe możliwości technologiczne, pogłębiamy dyskusję na temat nowoczesnej energii. Mamy za sobą trudne doświadczenie transformacji związanej z gospodarką rynkową i cały czas zmagamy się z różnego rodzaju czasochłonnymi procesami rozwojowymi wobec najbardziej zaawansowanych gospodarek. W tym sensie jesteśmy więc między grupą krajów, które stanowią awangardę światowej polityki klimatycznej i często zmiany klimatu traktują jako problem natury etycznej, a gospodarkami tzw. wschodzącymi, formalnie należącymi do grupy państw rozwijających się, dla których priorytetem numer jeden wciąż pozostaje wzrost gospodarczy i walka z biedą. Dialog z innymi państwami na arenie międzynarodowej jest bardzo dla nas istotny. Polska aż cztery razy pełniła rolę gospodarza i prezydenta Konferencji Stron Konwencji Klimatycznej. Za każdym razem były to ważne wydarzenia dotyczące ochrony środowiska i transformacji polityki klimatycznej. Podczas szczytu COP24 w Katowicach w 2018 r. mieliśmy możliwość zaproponowania kolejnych inicjatyw i rozwiązań, które nadal pozostają aktualne i ważne. Wśród takich założeń znalazły się działania na rzecz poprawy jakości powietrza, rozwój elektromobilności i czystych technologii, wspieranie zrównoważonego gospodarowania lasami oraz pozostałe działania w kierunku sprawiedliwej transformacji. 
Unijna polityka klimatyczna stale przyspiesza. Jakie będzie miała znaczenie dla dalszej integracji europejskiej i polityki europejskiej RP?

Europejski Zielony Ład jest flagowym projektem Komisji Europejskiej. Nie może to dziwić, gdyż transformacja w kierunku gospodarki neutralnej klimatycznie jest wyzwaniem bezprecedensowym, które dotyka każdej dziedziny życia. Wcześniej czy później wszystkie polityki unijne będą musiały być uzgadniane z wytyczonymi celami klimatycznymi. I my jako Polska jesteśmy do tego przygotowani. Utworzenie Ministerstwa Klimatu i Środowiska jest właśnie takim syǵnałem, że chcemy lepiej koordynować te tematy w kraju, a w Brukseli prezentować spójne stanowisko. Będziemy zaangażowani merytorycznie, starając się, żeby we wszystkich tych politykach zostały uwzględnione polskie interesy, ale zarazem będziemy pilnować równowagi instytucjonalnej w UE, tak aby wszystkie instytucje, w tym Rada Europejska, pozostały dalej zaangażowane w kreowanie wspólnej polityki.

Polityka klimatyczna to wyzwanie, ale także szansa. Biorąc pod uwagę Pana doświadczenie naukowe, pragnę zapytać o wizję przedsięwzięć związanych z zieloną gospodarką i o jej wpływ na klimat. Jak działałaby taka gospodarka w scenariuszu idealnym? Jakie mogą pojawić się największe bariery na drodze do jego realizacji? Gospodarka neutralna dla klimatu to taka, gdzie wyeliminowane są emisje gazów cieplarnianych netto. Co to oznacza? W każdym sektorze coś innego. Największym źródłem tego typu emisji jest obecnie produkcja energii elektrycznej i ciepła - będziemy musieli tu przejść na odnawialne źródła energii takie jak wiatr, słońce, ale też energia jądrowa czy geotermia. Technologie te są już szeroko dostępne, pewną natomiast barierę technologiczną stanowi magazynowanie energii i bilansowanie sieci. $\mathrm{W}$ transporcie będziemy musieli się przesiąść do samochodów elektrycznych i napędzanych wodorem, ale i również $\mathrm{w}$ większym stopniu korzystać $\mathrm{z}$ car-sharingu, transportu zbiorowego czy po prostu roweru. Na pewno wielkim wyzwaniem stanie się eliminacja emisji z transportu lotniczego, bo przyzwyczailiśmy się do szybkiego podróżowania na ogromne odległości, a nie dysponujemy jeszcze technologiami elektrycznych czy wodorowych samolotów. Poza tym wielkie wyzwanie czeka przemysł, gdzie dokonuje się wiele procesów technologicznych, w których dochodzi do emisji gazów cieplarnianych. Tu musimy też zdać się na przyszłe innowacje, wynalezienie alternatyw 
dla tych procesów, a w najgorszym razie wyłapywanie i przetwarzanie gazów cieplarnianych w trakcie produkcji. Ostatnim wielkim sektorem wymagającym przemian jest rolnictwo - jak wiemy tu także "proces technologiczny" wiąże się z emisjami naturalnymi. Na pewno w czasach gospodarki neutralnej klimatycznie nie będziemy mogli pozwolić sobie na taki jak obecnie poziom produkcji zwierzęcej i musi się to wiązać z rozłożonymi na lata zmianami w diecie i przyzwyczajeniach ludzi. $Z$ drugiej strony rolnictwo jest tym sektorem, który - przy odpowiednim gospodarowaniu - może przyczyniać się do pochłaniania gazów cieplarnianych w glebie i roślinach, dzięki czemu emisje będą skompensowane. W tym także liczymy na lasy, które pochłaniają ogromne ilości dwutlenku węgla - w przyszłości nie tylko trzeba zatrzymać proces wylesiania na świecie, ale również przywrócić lasy na niektórych terenach i prowadzić zrównoważoną gospodarkę leśną. W przyszłości człowiek zatem będzie musiał nauczyć się intensywniej gospodarować na mniejszej powierzchni, czerpać energię z naturalnych źródeł, a resztę pozostawić naturze. 